\section{Effect of Histones and Protamine on the Infectivity of Semliki Forest Virus and its Ribonucleic Acid}

Histones and protamine are associated in vivo with nucleic acids. The effect of these basic proteins on the infectivity of Semliki Forest virus and its ribonucleic acid (RNA) was investigated under physiological conditions in order to obtain a model of viral replication in vivo. Viral RNA has a low infectivity when assayed under physiological conditions and is rapidly destroyed by RNase in animal sera ${ }^{1}$ and at the cell surface ${ }^{2}$.

Chick embryo fibroblasts were prepared ${ }^{3}$ using $4 \times 10^{7}$ cells in each $60 \mathrm{~mm}$ Petri dish. No attempt was made to wash the RNase from the monolayers of chick embryo fibroblasts. Virus was grown in mouse brain, and RNA was extracted from infected mouse brain with redistilled phenol at $50^{\circ} \mathrm{C}$ (rof. 4). The RNA was extracted into 0.02 molar phosphate buffer at $p \mathrm{H} 7 \cdot 4$ containing $10^{-3}$ molar sodium sequestric acid and 10-2 molar tris (hydroxymethyl)-aminomethane $p H$ 7.4. The RNA samples were stored at $-70^{\circ} \mathrm{C}$. The RNA was assayed on chick embryo fibroblasts with a hypertonic salt solution (1 molar sodium sulphate containing 0.05 molar tris, $p \mathrm{H}$ 7.4). It had a titre of $3 \times 10^{\circ}$ plaque forming units (P.F.U.)/ml. and was destroyed by $10^{-4} \mu \mathrm{g} / \mathrm{ml}$. of erystalline bovine pancreatic RNase at $37^{\circ} \mathrm{C}$ in blood electrolyte solution (BES), $p H \mathbf{7 \cdot 4}$ (ref. 5). The RNase destroyed 90 per cent of RNA infectivity in $1.96 \mathrm{~min}$. BES was used to dilute the basic proteins and RNA and 10 per cent foetal calf serum was added to dilute the virus.

The protamine sulphate used was extracted from fish roe, and was free from preservatives. The histones were extracted as sulphates from fowl red cell nuclei and from calf thymus.

To assay the infectivity of virus and RNA under physiological conditions, the growth medium was removed from the chick embryo fibroblasts and replaced by $2.5 \mathrm{ml}$. of BES or BES containing $100 \mu \mathrm{g} / \mathrm{ml}$. of one or other of the basic proteins being tested. This was removed after $30 \mathrm{~min}$ and $0.2 \mathrm{ml}$. of suitable dilutions of virus or RNA was added to the monolayers. In some experiments, $100 \mu \mathrm{g} / \mathrm{ml}$. of one or other of the basic proteins was mixed with virus or RNA at the time of inoculation. Inocula containing virus were left in contact with the monolayers for $2 \mathrm{~h}$ and inocula containing RNA for $10 \mathrm{~min}$. The inocula were removed and the monolayers were overlaid ${ }^{3}$ and plaques which had appeared in $48 \mathrm{~h}$ were counted after adding neutral red. The assays were carried out at $37^{\circ} \mathrm{C}$ and all solutions and apparatus were at this temperature. All experiments were done in duplicate and the average plaque counts of both plates are shown in Table 1.

Table 1 shows that pre-treatment of the chick embryo fibroblasts with calf histone halved the infectivity of the virus, while pre-treatment with fowl histone reduced the infectivity 9-12 times. The virus infectivity was reduced to 20-25 per cent with protamine pre-treatment. The presence of basic proteins in the virus inoculum had little or no effect on the infectivity.

Pre-treatment of the monolayer with calf histone and fowl histone reduced the infectivity of RNA. On the other hand, in the absence of histone pre-treatment, calf histone in the RNA inoculum reduced the infectivity but fowl histone did not. Pre-treatment of the monolayers with protamine alone doubled the RNA infectivity and when

Table 1

\begin{tabular}{|c|c|c|c|}
\hline \multirow{2}{*}{$\begin{array}{l}\text { Pre-treatment of mono- } \\
\text { layer with BES + }\end{array}$} & \multirow{2}{*}{$\begin{array}{l}\text { Inoculum of virus or } \\
\text { RNA contained BES + }\end{array}$} & \multicolumn{2}{|c|}{ Titre (P.F.U./ml.) } \\
\hline & & & 16 \\
\hline Calf histone & $\overline{-}$ & 177 & $\begin{array}{r}10 \\
4\end{array}$ \\
\hline & Calf histone & 8 & $<4$ \\
\hline Fowl histone & - & & $<4$ \\
\hline Protamine & Fowl histone & $\begin{array}{l}15 \\
42\end{array}$ & $\begin{array}{l}<4 \\
30\end{array}$ \\
\hline & Protamine & 3 & 116 \\
\hline - & Calf histone & 15 & $<4$ \\
\hline - & one & & \\
\hline - & Protamine & 147 & 95 \\
\hline
\end{tabular}

combined with protamine in the RNA inoculum the infectivity was raised seven times. When protamine was present in the inoculum alone the RNA infectivity was increased six times.

Histones may have some RNase activity ${ }^{6}$ and an alteration of RNase activity in the tissue culture system by the basic proteins might change the RNA infectivity. In order to test this possibility an RNase assay system using yeast RNA and $0.1 \mu \mathrm{g} / \mathrm{ml}$. of bovine pancreatic RNase was used ${ }^{7}$ to compare the digestion rate of enzyme with similar enzyme mixtures containing $100 \mu \mathrm{g} / \mathrm{ml}$. of protamine or calf histone or fowl histone. No difference in RNase activity was found between the control and the mixture containing the basic proteins. Thus, under the conditions used, these basic proteins had no effect on the RNase activity; this suggests that the enhancement of RNA infectivity by protamine was not a result of inhibition of RNase in the tissue culture system.

Histones have been shown to inhibit cellular RNA synthesis ${ }^{8}$, and our results show that calf and fowl histone reduce both virus and RNA infectivity in chick embryo fibroblasts. Fowl histone was the most effective in reducing the virus infectivity and it may be that the suppression of virus infectivity is more efficient when the histone is species specific. The effects noted with histones may be different from that which occurs in vivo as they may be altered during the acid extraction process or by proteolytic enzymes released during preparation or present in serum.

It is clear from the results in Table 1 that protamine reduces virus infectivity but increases RNA infectivity. This suggests that protamine has a different mode of action from that of histones. A modification of the cell membrane ${ }^{9}$ or an effect on the RNA itself ${ }^{10}$ has been suggested to explain the effect of protamine on RNA uptake by cells.

Protamine sulphate and fowl histone sulphate were kindly prepared by Evans Medical, Speke, Liverpool, and calf thymus histone by Dr. I. Leslie, Department of Biochemistry, Queen's University of Belfast.

\section{J. H. Connoluy}

Department of Microbiology,

The Queen's University,

Belfast 12.

${ }^{1}$ Alexander, H. E., Koch, G., Mountain, I. M., and Van Damme, O., J. Exp. Med., 108, 493 (1958).

2 Norman, A., and Veomett, R. C., Virology, 14, 497 (1961).

${ }^{3}$ Porterfield, J. S., Bull. Wld. Hlth. Org., 22, 373 (1960).

" Wecker, E., Virology, "7, 241 (1959).

' Connolly, J. H., Herriott, R. M., and Gupta, S., Brit. J. Exp. Path., 43, 392 (1962).

- Martin, S. J., England, H., Turkington, V., and Leslie, I., Biochem. J., 89, 327 (1963).

${ }^{7}$ Connolly, J. H., Herriott, R. M., and Gupta, S., Brit. J. Exp. Path., 48, 402 (1962).

8 Huang, R. C., and Bonner, J., Proc. U.S. Nat. Acad. Sci., 48, 1216 (1962). Barr, G. C., and Butler, J. A. V., N Nature, 199, $1170(1963)$. Allfrey, V. G.

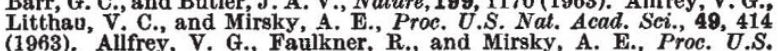
(1963). Alifrey, V. G., Faulkner, R., and Mirsky, A. E., Proc. U.S. and Shapiro, I. M., Nature, 208, 557 (1965).

-Amos, H., and Kearns, K. E., Exp. Cell Res., 32,14 (1963).

${ }^{10}$ Smull, C. E., and Ludwig, E. H., J. Bacteriol., 84, 1035 (1962).

\section{Incomplete Antibodies in Rhinoscleroma}

MANY authors have made use of the Coombs reaction in investigations of incomplete antibodies in bacterial and rickettsial infections.

The purpose of my investigation was to determine the occurrence of incomplete antibodies in rhinoscleroma using the Coombs reaction to diagnose rhinoscleroma. I have been unable to locate any previously published data concerning these antibodies in the literature available to me.

I examined fifty-four sera from patients with rhinoscleroma, forty sera from healthy subjects and sixteen sera from rabbits inoculated with Klebsiella pneumoniae 